\title{
The Lyric Struggles of John Gawsworth
}

\author{
STE VE E N G
}

\author{
He, without a penny \\ May yet hold that pen \\ Which turns disdain of many \\ To the praise of all men.
}

-John Gawsworth

The late "John Gawsworth" (1912-70) was variously a weak poet, a good poet, an astute poetry editor, and a great poetry collector. Yet his posthumous legend centers on his lighthearted "kingdom" of Redonda, that Caribbean island that he never saw. ${ }^{1}$ In literature, his horror fiction anthologies and campaigns for fantaisistes like Arthur Machen and M. P. Shiel are more remembered than his outof-print poems.

Yet Gawsworth's poetry won him early praise, and he wrote considerable verse right through the last year of his life, filling numerous notebooks many of which are now at Iowa. Surely his poems merit a second look. His long-continued battle for traditional lyrics should also find its place in an unbiased history of modern poetry.

He was born in London as Terence Ian Fytton Armstrong. Part Irish and to a less extent Scottish ("Jacobite" he claimed), he never tired of listing his possible poetic ancestors, direct or remote-such as Mary Fytton of Gawsworth Hall, reportedly (but not actually) the "Dark Lady" of Shakespeare's sonnets-or Ben Jonson-or 1890's aesthete Lionel Johnson-or Milton's third wife. Though he hated school, never attending a university, he was proud of his graduation from the respected Merchant Taylors' School, where one of his idols had also gone, tragic Edwardian poet Richard Middleton. The school magazine published Armstrong's early bookish verses.

1 Jon Wynne-Tyson, "Two Kings of Redonda: M. P. Shiel and John Gawsworth," Books at Iowa, no. 36 (April 1982): 15-22. 
Then his mother left for Canada, divorcing a father whom the son claimed hated him. Left behind, teenaged Armstrong worked for a bookdealer, while also buying and selling rarities on his own. He was rapidly acquiring countless volumes of nineties, Edwardian, and Georgian poets who would greatly influence his own poetry. Soon he was compiling bibliographies of those who were still living, seeking them out, occasionally lobbying to get them Civil List pensions. Often they gave him books and manuscripts; he would scout out other of their forgotten or unpublished works in bookstores and auction rooms. His discoveries began appearing under the aegis of his pen name, "John Gawsworth." As he progressed to editing magazines, the influx of poetry manuscripts and inscribed presentation copies mounted. To the end of his life Gawsworth trafficked in poetry books and poets' letters and memorabilia.

Now book collectors do not often aspire to become significant poets-even fewer poets and authors worry much about first editions -and rare is that critic of literature who takes seriously bibliographical "points" like large-paper editions and signed, numbered copies. Somehow Gawsworth combined it all: the collecting, editing, selling, and writing of poetry. According to Herbert Palmer, as a bookman Gawsworth was "almost certainly the best informed of any under thirty years of age" 2 and his off-trail literary knowledge, in the words of Kenneth Hopkins, lay "far outside the range of nine English professors out of ten." 3

Gawsworth began issuing his own verses in 1890s-like broadsides and pamphlets. His first collection, Confession (1931), has a title that is perhaps only the wishful sinning of a 19 year old. This figurative worldliness is further evoked by "swaying Bacchanates" and Dowson-like ashes of "dead desire." Ernest Dowson's ghost hovers over Kingcup (1932) as well, with "sick at heart" (twice), "laughter and wine," and "I was desolate." Reviewers complained, and in later editions the offending examples are dropped or corrected ("sick at heart" becoming "tired of heart"). Actually Kingcup was praised by Lawrence Durrell; and Mishka and Madeleine (1932), despite its Beardsleyesque art, contains some strong Shakespearean sonnets such as "Carpe Diem":

Read me no tale that has not love for theme;

I will not hear those chronicles of gloom,

2 Herbert Palmer, Post-Victorian Poetry (London: J. M. Dent, 1939), p. 366.

3 Kenneth Hopkins, "A Little Piece about Me \& John Gawsworth," forthcoming in Romantist. 


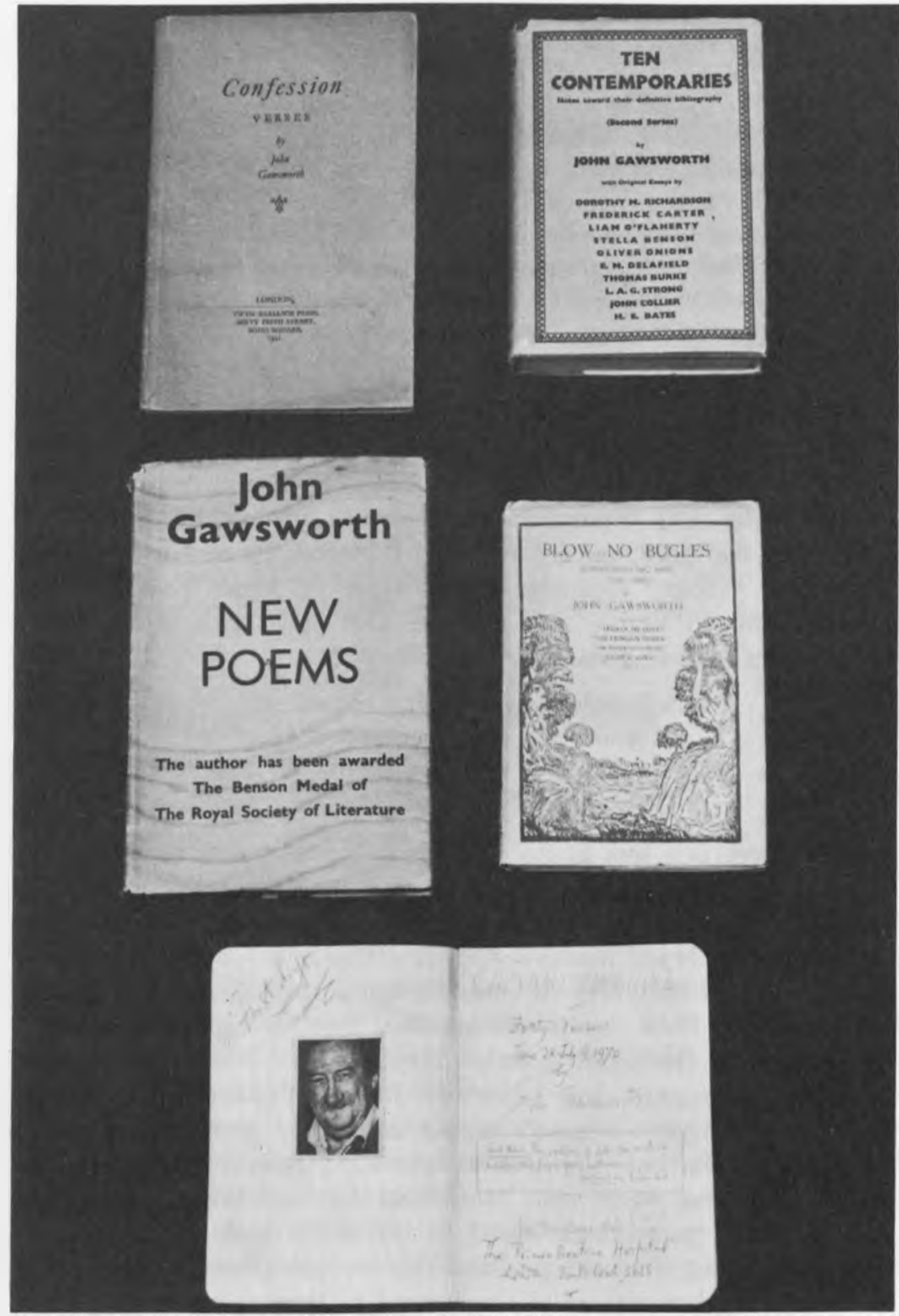

A selection of writings by the English poet John Gawsworth (1912-1970), ranging from Confession (1931), his poetry debut, to Calvary Continued (1970), an unpublished late notebook. From the collections of The University of Iowa Libraries. 
Lacking the savour of life's fondest dream, Telling of virgins in the loveless tomb.

We should be happy for our mortal spell.

Too soon the unbanked fires of life burn low.

Manon and Mimi may have loved too well,

Yet at the summons they were loth to go.

Brief is contentment, short are honied hours.

Time, swift and sure, soon scythes all blooms to stalk.

Let's make the Present wonderful whilst ours,

Lost in our love, dispense with needless talk.

Do you not know that all narrated bliss

Is but a fingersnap to your next kiss?

Others from Three Friends, Fifteen Poems (1931) during this period struck the pastoral note. The city-bred Gawsworth still liked to visit Wales, and "Roman Headstone" was inspired by a graveside in Wales, the poet musing on a girl buried 16 centuries before. "Llanthony Abbey" is another rumination on times past conjured by stones in old Wales. And "Regret" also plays with liquid Welsh place names in its first stanzas.

We will return together and go down

The strawberry lane that curves to Llanthony,

And trudge across the acres brown

Of Llanvilhangel's lea.

Such poems are less in the nineties mode than that of the "Georgians," whose movement started the year of Gawsworth's birth. Like many a poetry "school" the Georgians had rallied more around a publication (Edward Marsh's 1912-22 anthologies) than around firm principles. Still they had in common plain speech, not fin-de-siecle exoticism, and their poems exhale clean English air, not incense or hashish fumes. De la Mare, Ralph Hodgson, and Robert Frost could be called Georgians, but especially Rupert Brooke, who inspired Marsh's anthologies. Brooke's sonnet accurately predicting his own death was a wartime, sentimental favorite. However, the easily parodied Georgians were soon scoffed at as "lark-lovers" or "weekenders" (fake pastoralists, based in the city); and World War I's reality-trenches, mustard gas-and the modern poetry revolt (imagists, vorticists, futurists, et al.) conspired to bury them. Pound, Eliot, and their allies triumphed; poetically, it seemed that Rupert Brooke had died in vain. Yet for all their insipid weakness, the Georgians had briefly caught the ear and reached the heart of the average English reader. Later poetry cliques could scarcely claim such success. Strag- 
glers from the movement would be dubbed "Neo-Georgians" by Herbert Palmer, a mentor of Gawsworth. The young bookman would seek them out personally with naive enthusiasm.

The Georgian economy and precision were good apprentice models for Gawsworth, and their short lyric flights suited his brief attention span. His perfect "Animula" (Poems, 1938) glows with Georgian sunniness.

Where the definite earth

Met the indefinite sky,

A rainbow gave birth

To a butterfly.

It flashed in the morn

Aloft from its bed-

The newly born

Like the newly dead.

Another verse from the same volume, titled "Gossip," is smoother than some of Housman's poems of similar topic and tone.

A breeze in the barley

And gossip is there;

A thousand heads whispering

A secret laid bare.

A thousand wise heads

A-nod in the sun;

The joy on their faces!

The shame on one!

Certainly that is a neat, memorable comment on small-town crueltyHawthorne's Hester Prynne, or Hardy's Tess would have agreed. As for Housman, Gawsworth now shared the same publisher, Grant Richards; and Poems (1938) was conspicuously uniform (and so advertised) with Housman editions.

But writers of terse quatrains often risk triteness, at worst composing unintentional greeting-card verse. Poet Hugh Gordon Porteus types Gawsworth's lesser poems as "the product of a Georgian or Victorian Sausage-machine, fat, smooth-grey or pinkish lengths of stodge." Gawsworth's weakest are surely thin, and Durrell while

4 Hugh Gordon Porteus, "A Few Dry Leaves," Book Collecting \& Library Monthly [U.K.], no. 28 (September 1970): 132. A 1962 memoir of Gawsworth. pp. 132-134. Porteus met Gawsworth in the thirties over a mutual interest in Wyndham Lewis, one modernist for whom Gawsworth made an exception. He in fact wrote a book about Lewis. 
praising some has called others "wishy-washy."5 $\mathrm{He}$ also placed Gawsworth's craft into the cavalier tradition of Herrick, suggesting that he lacked the expansiveness of the Elizabethans. His work is also flawed with the minor fault of inversions, as well as "eye" rhymes like "love/move" or "wars/scars" (though this latter occurs in Eliot and Alun Lewis). Now and then the reviewers chided Gawsworth for being too facile, a likely charge against such a poet-bookman.

He began to break such monotony by varying his line lengths, as well as by inserting abruptly startling words-sometimes an archaism, sometimes a word deliberately ugly. This latter tactic does not always succeed; it is a virtue and a vice with Hardy also, one of Gawsworth's idols. Roy Campbell observes that "whenever Gawsworth is in danger of getting too smooth, flowery, or pretty in his speech, he can generally be relied on to balk the danger with some robust and original image." 6

Reviewers usually credited Gawsworth's lyric gifts, such as Mona Gooden: "He possesses an almost flawless ear" 7 and "Some of these moth-like pieces possess a fragile perfection reminiscent of Chinese craftsmanship." 8 John Masefield called him "one of the most beautiful and promising of our younger poets" 9 and Lascelles Abercrombie said, "John Gawsworth's poetry just is poetry-what poetry always has been (and always will be). There is a real, firm, shapely and self-subsisting beauty in what he writes."10

Such praise from older writers barely suggests the amazing depth to which Gawsworth was immersed in other poets' work. While still 19, he assembled Ten Contemporaries (1932), including bibliographies on and essays by poets Wilfrid Gibson, Robert Nichols, Herbert Palmer, Abercrombie, and notably, Edith Sitwell. Gawsworth later claimed to have met Miss Sitwell at an antivivisectionist meeting, where medical students started a fight and the two of them were

5 Letter, July 20, 1961, in Ian S. MacNiven and Harry T. Moore, eds., Literary Lifelines: The Richard Aldington-Lawrence Durrell Correspondence (New York: Viking Press, 1980), p. 180.

6 Roy Campbell, "The Poet of the Free Man," Enquiry [U.K.], 2, no. 2 (August 1949): 59. Campbell's essay is a five-page review of Gawsworth's Collected Poems.

7 Mona Gooden in Dublin Magazine [U.K.], new series 18, no. 3 (JulySeptember 1943): 84.

8 Ibid., new series 13, no. 4 (October-December 1938): 71.

9 J. H. R. Owen, John Gawsworth: Some Publications 1931-1944 (Italy: privately printed, 1944), p. 2.

10 Lascelles Abercrombie, "Introduction" to John Gawsworth, New Poems (London: Richards. 1939), p. 7. 
shoved jointly out the back door; she invited him for tea, and for a time he was her "bun boy" at weekly gatherings.

Also in 1932 his Twyn Barlwm Press (named for a Welsh mountain) printed poems by Sitwell, Palmer, Edmund Blunden, and W. H. Davies, a poet he quite resembles. Gawsworth would later say that Davies's "lyrical note and disillusioned message always appealed to me."11

Seeking out poets and poems made Gawsworth into an intrepid anthologist. In 1932 Michael Roberts's New Signatures touted the university poets Auden and Spender. Gawsworth riposted with his Known Signatures that same year, which owed partly to his book scouting, featuring poems by Dowson, Middleton, various Georgians, and Neo-Georgians, and modern figures like Sitwell and Scottish nationalist Hugh MacDiarmid. Its charming green cover decorated with red enhances its traditional tone, fulfilled by the defiant introduction which flings down a gage to the modernists, in a paraphrase of Marc Antony's oration:

Judgment has not fled to brutish beasts, but to incompetents, it would seem. Men have boastfully lost their reason. The course of English Poetry has deviated far enough now from the channels of tradition in many cases hardly to be called poetry. It is sinking underground into the marish morass of incoherence, led there through the cloaca of experiment ( $p .13$ ).

Gawsworth was only 20 . When at later times he criticized the modernists in print (and it was rare), he was understated and oblique. In 1933, A. E. Housman rose in defense of lyric verse in "The Name and Nature of Poetry" and in the U.S.A., Stanton A. Coblentz started his journal Wings. Coblentz's combative editorials and later books attacking modern verse would assure his boycott down the years. Being generally more diplomatic, Gawsworth was at least fairly tolerated for 20 years. Privately, he would help almost any poet, often mounting petition drives for ailing, older writers. Durrell once tested this, pretending that Auden and Spender (whose poetry Gawsworth deplored) were in near-starvation, and he rose to the bait. He was ready to rush out with petitions on their behalf till the joke was divulged.

In February 1936, Gawsworth launched his "back-to-the-lyric" movement with Edwardian Poetry Book One: 1936 (1936). Earlier, Edward Marsh had sought to tie his Georgians to the reign of a new

11 Eric Phillips, interview, "H.M. The King of Redonda," Writer [U.K.] (October 1962): 4 . 
king, George V. Gawsworth copied this ploy. The volume opens with a fawning dedicatory poem to Edward VIII by one of Gawsworth's allies, the coronation having occurred the previous month. Poets like Ruth Pitter, Anna Wickham, MacDiarmid, and the brilliant South African Roy Campbell distinguish the anthology. (These last two poets would later write prose tributes to Gawsworth, themselves becoming virulent foes over the Spanish Civil War.) As he had learned to do in his own verse, Gawsworth had banished the worst Georgian "moonshine" from his selections. The anthology was anonymous, and thus amply represented Gawsworth's own poems. One reviewer summed up its nameless editor's position well: "Has apparently been collected by someone who believes in Tradition and Lord Tennyson and No Damn Nonsense."12 (The unsigned prefatory note had boasted that no free verse was included.)

Unhelpfully, however, Edward VIII abdicated and momentarily Gawsworth's fledgling campaign was without a namesake-figurehead. (Privately he was elated, staying up the night the news was announced to drink gay toasts to the living Jacobite Stuart pretender.) As for his poetry crusade, Gawsworth seized the leftover name of the earlier Georgians, since conveniently another George (the VI) had begun to reign. The next book was Neo-Georgian Poetry 1936-1937. From this book, his own "From the Deep" rather typifies the kind of lyrics to be found in the anthologies (there were no more in the series).
When women look upon their lovers
They do not see their loves, but gaze
Out on a landscape where their fancy,
Like sunshine, plays.
When women speak unto their lovers
Often they do not choose their words,
But loose, unwitting, on bright pinions,
Phantasmal hirds.

Another anthology was the quaint The Muse of Monarchy (1937), assembling the poems of the kings and queens of England. Did Gawsworth have deluded aspirations to the laureateship? A journalist in 1960 would assert that he had once been considered as Masefield's eventual successor. This is probably fiction, though in a satirical novel about poets vving for the post (Dylan Thomas and John

12 Irish Review, quoted on dust wrapper of Neo-Georgian Poetry 1936-1937 (London: Richards Press, 1937). 
Davenport, The Death of the King's Canary, 1976), Gawsworth is lampooned, along with brighter names, as Mallow, a bibulous bibliophile. Certainly he had compulsive laureate tendencies, writing adequate elegiac verses to Edward Thomas, M. P. Shiel, George VI, and Dylan Thomas, among others. With good-natured fin-de-siècle unction, many of his verses, too, are dedicated to the living.

Gawsworth's lesser anthologies are The Public School Poets, three 1934 volumes by famous poets as well as nonentities, all of whom happened to go to Eton, Harrow, or to his own Merchant Taylors'. There was also The Garland of Erica (1938), which included verses by Sturge Moore and Anna Wickham. At least three more anthologies were never published. ${ }^{13}$

Meanwhile Known Signatures dropped its hostile introduction and evolved into Fifty Years of Modern Verse (1938, reprinted 1949). Gawsworth was editing collections of individual poets as well, such as Havelock Ellis, nineties decadent Theodore Wratislaw, his idol and Redonda predecessor M. P. Shiel, and his Edwardian favorite, Richard Middleton. The latter's childlike soul, drifting personal life, and suicide struck a chord with Gawsworth; the same temperament existed in Ernest Dowson. Additionally Dowson committed suicide the slow wav, through drinking, the method ultimately chosen by Gawsworth. He delivered a scathing lecture, "The Dowson Legend," to the Royal Society of Literature, refuting any exaggeration in the accounts by other writers of Dowson's dissolution. As an excuse for the drinking, he stressed the suicides of Dowson's parents. ( $\mathrm{He}$ had of course himself been distanced emotionally from his father, geographically from his mother.) He located overlooked Dowson poems, lost letters, promoted a Dowson society (with anniversary graveside ceremonies), and wrote one hundred pages toward a biography of Dowson (surviving at Iowa). In the forties, Mark Longaker would seek out Gawsworth as he prepared his own standard biography; as with Middleton, Gawsworth had located anvone who had known Dowson.

This hectic activity plus his own prolific verse (eight volumes between 1931 and 1938, one thrice reprinted) made him the youngest

13 (1) Twenty Lyrics (c.1934) aimed at updating Palgrave and other standard collections. Compiled with Hugh MacDiarmid, who was living with Gawsworth at the time, its joint introduction rails at the modernists, a fact which may explain its oblivion (it survives at the University of New York at Buffalo). (2) The Oxford Book of Suppressed Verse-Lawrence Durrell once intended to publish; this ribald compilation is sadly lost. (3) Liber Amicorum (1935-49) was a manuscript album of verse gathered from 44 friends, including Durrell. de la Mare, James Stephens. and Seumas O'Sullivan. It also is lost. 
fellow elected to the Royal Society of Literature and earned him its Benson Silver Medal for services to poetry in 1939.

In his own poetry, the counterfeit nineties diction was now gone, along with most of the Georgian staleness. His verses about love had grown even crueler. In New Poems (1939), "Nihility" talks first of burying Love where it cannot be found, then

I have put it away dumbly.

There was no word spoken.

A sudden jerk of the head

And the neck was half-broken.

I laid Love away

And kept no token ...

In this book Herbert Palmer found Gawsworth "even bitterer and more disillusioned than A. E. Housman,"14 a tendency emphasized in The Mind of Man (1940), as in "Advice of Juan" which begins

I am a vampire of love

And gorge upon it.

I fret a fury

And erupt a sonnet

In selfish arrogance

I crush the mood

Between black wings

And spill what is my food...

Other verses are begloomed with contemporary war clouds such as these lines from "Europe":

I hear bells spilling

The silver shilling

Of Emperor Death on Man's conscripted palm,

Hear the brave clarion as they carry on

The last enlistment, tense and calm.

In Marlow Hill (1941) there is a tribute to a dead war poet, Bertram Warr, with at least a touch of optimism: "The bomb obliterates. The dream remains." But "Dirge" is in his more usual bleak mood, where "The sword is not rusting/But the ploughshare."

Already his poems were appearing in anthologies, such as Thomas Moult's annual Best Poems. In 1939 he founded the long-running English Digest which also used poems and occasionally articles by poets. per.

14 John Gawsworth, The Mind of Man (London: Richards, 1940), dust wrap- 
He had been working at a publisher's in the thirties and had also married (the first of three unsuccessful tries). Then in 1941 under his real name, Armstrong, he enlisted in the RAF after medical rejections by the army. He left behind Legacy to Love (1943) as a possible monument. Its introduction casts a Rupert Brookian eye toward possible immortality by bullet ("should circumstances prevent my writing more"), and the last poem in the book is a precautionary, potential epitaph. As a sort of poetic life insurance, it asserts that "The conscript as a craven can/Outface the boaster and the brave," closing

So I must be considered one

Who fought to save his farm and field

And left his shy place in the sun

To prove not even poets yield.

One must smile at this rustic note, since Gawsworth the nostalgic Londoner was more at home in the book-lined garret, in the bookshop with its sidewalk penny bins, or especially in any good poets' pub. At least one reviewer prayed he would survive to write more poetry.

However Gawsworth was not to die and rest in "some corner of a foreign field/That is for ever England"; in the war, he characteristically collected books, not bullets. Sent to Algiers, he spent every moment on the ground tracking North African literature, much of it poetry. He would rescue water-logged, mud-covered volumes from deserted villas, or buy them by the pack load; he visited one noted poet in the hospital: it all went into a lecture delivered and published after the war. He even penned a wartime poem in the usually despised free verse, which Nancy Cunard translated for Poems for France (1944); it so moved a celebrated French author and airman, Colonel Jules Roy, that he flew across the desert to meet Gawsworth. Also, presumably for poetic not military services, he was honored by the bey of Tunis with an escort of lancers into his city, and appointment into his personal order. In Cairo, Gawsworth was one of the British "Salamander" war poets; in Italy he wrote a poem in the room where Keats died, had his verses translated, visited Croce and gave him food from his knapsack, and at some ceremony had himself garlanded with flowers. He issued a stream of poetry booklets during the war, mostly in private editions from Vasto, Italy (where Christina and Dante Rossetti's father was born, he would point out). In Calcutta a regular publisher brought out his verses and the anthology Fifty Modern Poems by Forty Famous Poets (1945). He published an essay on Anglo-Indian literature as well. 
Most notable of Gawsworth's war verses is "Moving Back" from Out of Africa (1944):

We are going back again

To the mud and the rain

Where the guns complain

And the stones stain.

We are leaving the mountain snow.

Once more it is our turn to go

Back to the advanced foe.

It is just we know ...

We are going back again

To our comrades' graves on the plain,

To the graves sunk in the rain:

We do not complain.

We say nothing: but think only

(Heart-constricted, a moment lonely):

"Who will be killed this time-

And for what crime?"

Line 4 is too close to the "stained stones" in Wilfred Owen's "Greater Love"; but the poem is the sort that would have been reprinted had Gawsworth died in uniform. Another one might be "Rest" from Into Europe (1944) with soldiers lying on their backs looking at open sky, unmindful that "Death is at work this sunny day,/Life has no time for holiday,/Soon these will go their comrades' way." Mark Longaker notes that to Gawsworth "war is largely a background for sentiments which belongs to the undulating life of man. The poems are never hortatory. And rarely does satire enter." 15 Gawsworth is represented in several war-poetry anthologies, and his best deserve preservation. His traditional form stands out; he was really writing World War I poems nearly 30 years after. Meanwhile, the brighter poetic reputations belong to names like Sidney Keyes, who died in North Africa, and Alun Lewis, who wrote tellingly of India before he died.

Back from the Far East, he was soon busy editing three magazines at once, chiefly the Poetry Review for the Poetry Society which to a younger poet like Derek Stanford seemed "rather like an old

15 Mark Longaker and Edwin C. Bolles, Contemporary English Literature (New York: Appleton-Century-Crofts Inc., 1953), p. 251. 
folks' home for retired Georgian poets." 16 Its reactionary editor was "Chevalier" Galloway Kyle, till ousted in a coup d'état that installed Muriel Spark, a flaming modernist. She in turn irked such grand literary dames as Marie Stopes, an early Gawsworth mentor, and was fired. Her cadre of younger bards stormed out. Thus in late 1948 Gawsworth was appointed, editing 20 issues that nimbly steered between traditional and modern extremes. He published Richard Aldington, Roy Campbell, and MacDiarmid, war poets like G. S. Fraser and John Waller, contemporaries of note like John HeathStubbs, Lawrence Durrell, Wrey Gardiner, Michael Hamburger, and Jack Bayliss, as well as traditionalists like Lord Dunsany, de la Mare, and A. E. Coppard. Gawsworth's catholic, tolerant editing can be seen in articles he accepted on Pound, Auden, and Eliot. He even boasted that some readers called him "modernist."

In 1948 he readied his Collected Poems, letting G. S. Fraser, Ian Fletcher, and John Waller make many suggestions on the manuscript. It was brought out in 1949 (with a 1948 imprint date) by Rupert Brooke's old publisher, Sidgwick \& Jackson, and met fairly positive reviews, though even his own magazine noted he had reached a poetic stopping point, that a new course must. be charted. Reportedly, much of the edition became waterlogged and was destroyed.

At first the late forties would seem to have been Gawsworth's heyday-he made Who's Who, for instance. But his older writer friends had largely died off, and his modernist rivals were becoming an establishment. His drinking increased, and an indiscreet translation of Rimbaud he had accepted for the Poetry Review offended someone. In late 1952 he was dismissed, ostensibly to save the society money. Around 30 letters of support from writers such as Edith Sitwell and Eden Phillpotts avalanched upon the society but to no avail. This time, many traditionalists walked away in protest from the frequently tumultuous Poetry Society.

In 1951 Gawsworth edited a selection from Tennyson, and in 1953 he made one of Milton. (Earlier he had discovered some spurious poems embedded in standard Milton editions.) Then Gawsworth, who had had five hardcover books published by 1932, when he was barely 20 , would have no more books of any kind for the rest of his life. Alcoholic poverty increasingly became his lot. Often in

16 Derek Stanford, Inside the Forties: Literary Memoirs 1937-1957 (London: Sidgwick \& Jackson. 1977), pp. 152-53. Stanford was Muriel Sparks's strong advocate; for his negative assessment of Gawsworth, see pp. 212-15. 
poetry he had predicted the descent from grace ("When they fall men grasp at feathers," etc.). Despite this total divorcement from book publishing, he continued to fill notebooks with his poems. Over a dozen of these, containing several hundred verses written after the Collected Poems, found their way to Iowa. ${ }^{17}$

In 1961 Richard Aldington, shortly before his death, chose 57 of the Collected Poems for a new, selected edition titled Toreros. Gawsworth added Roy Campbell's essay, but Toreros was never issued, and the unpublished mock-up is now at Iowa. In 1962 on his fiftieth birthday some verses were read over the radio in France, and in England a bundle of tributes was assembled. Several of these have been published, such as Lawrence Durrell's; but the rest of the festschrift (around 50 essays, including one from T. S. Eliot) remains in private hands. In the late sixties Gawsworth's landlord sold his building; recklessly, for a sum of money, he surrendered his right to stay on. No other landlord would rent to him; without an address he could not receive social security; nor could he win that Civil List pension which he had secured for several other writers. In squalor and ruination, he had rather out-Dowsoned Dowson. By the winter of 1969-70, he was discovered sleeping in Hyde Park and became a news item. A fund was raised through the Times to rescue him. It was not, sadly, a mere case of providing warmth and care like the Meynells taking in Francis Thompson, or Watts-Dunton and Swinburne, though Ian Fletcher heroically tried. Gawsworth's talent for disaster now approached genius, and money in his hands meant suicide. Still, a lively television program hosted by Durrell was aired in the summer of 1970 . The BBC itself retains no file copy, but an excellent audiotape survives at Iowa. Many poets and writers participated. One hears besides reminiscences and poetry, corks popping and bottles pouring. The show closes with Gawsworth's poignant reading of "Jottings in the Dark," written that year in a hospital bed at four in the morning. In it he decided that "this disease/of an else-ordered brain/Called 'Poetry'/I find essen-

17 These are (1) The Golmohur Grove: Poems from India, 1944-1946; (2) Seventy-Two Manuscript Verses (1946-1950); (3) Polly: Sixteen Sonnets, etc. [1962]; (4) Deciduous Leaves: One Hundred and Twenty-Two Uncollected Poems (1929-1963) [1963]; (5) Fourteen Poems [1965]; (6) A Rhyme Ragôut 1964-1965; (7) Jingles: Two Hundred New Pieces (1965-66); (8) A Wife and Wonders: Forty Unpublished Verses (1940s-1950s) [1968]; (9) Affirmations and Airs: Forty Unpublished Poems [1968]; (10) Convalescence: Fifty New Verses [1968]; (11) Jottings in the Dark: Forty-Eight New Poems, 16 Dec. 1969 to 10 Jan. 1970 [1970]; (12) La Gianne (for Jane): Fifty New Verses, 21 April7 June 1970 [1970]; (13) Calvary Continued: Forty Verses (June-July 1970) [1970]. 
tially sane" yet admits that he is "cursed with poetry" which is almost like leprosy: "Oh, to stand untainted, healthy, free-/Damn you, Poetry!"

It was the title piece from one of his last verse collections. The next one was addressed to a new love he had met in Italy on a foolish, nostalgic trip in 1970. The succeeding collection (and the last one at Iowa) was called Calvary Continued, written back in the hospital: needless to say the "death" in its pages is no longer a Jacobean, poetic abstraction. A month or so later Gawsworth wrote a 50-verse sequence called Preoperation, going on to survive surgery for bleeding ulcers and continuing to write letters and more verses from his bed. Last poems were given to friends, such as to Arthur John Roberts and to Jon Wynne-Tyson. On September 23 he died in his sleep at age 59. At the memorial service Oliver Cox read from his verse, and in 1971 Cox issued Some Poems in further tribute. Around two hundred verses had been attempted in Gawsworth's last ten months, and a publisher was considering a book of some of these, then withdrew. With even sadder irony, some large legacies from deceased relatives were about to come through-and a chair of poetry in Ceylon (Sri Lanka) had been under strong consideration.

Gawsworth's brief vogue was of course in the thirties, and in 1962 Hugh MacDiarmid lamented how silent some of his earlier advocates had become. Certainly he was left out of anthologies and studies by writers whom he had helped. Sometimes it was politic to pass over Gawsworth to appease other persons who disapproved of him. His alcoholism was sometimes only a pretext; his out-of-fashion tastes and his precocious rise account for more. (Liquor or marijuana did not block acceptance of modern poets like Dylan Thomas, Allen Ginsberg, or Charles Bukowski.) Probably Gawsworth's detractors sensed that his derrière-garde stance might one day be partly vindicated. There is no more durable literary emotion than jealousy.

It is easy to say he was born too late. But in the crowded 1890 s or amid the many talented Georgians, Gawsworth's imitative tendencies might have made him an inconspicuous lightweight. Operating as he did decades later, as a professional anachronism, his traditional tastes actually gave him a strange strength by way of novelty. Also, he became more modern in desperate self-defense, attempting to purge the sentiment and verbiage that afflicted so many of his heroes. His verse is all the tougher for having been written in the age of Eliot, and later of Dylan Thomas. Its adolescent pain corrodes into a kind of jaded harshness that has its own contempo- 
rary tone; such terse brutality offsets his occasional want of imagery. There is also a lack of extended ideas, common enough in a lyric poet. Of course, Gawsworth shunned the long poem, making brevity almost a fault, though it is no less a fault in de la Mare and Emily Dickinson. One of his happiest traits borrowed from his nineties models was the sense of music; with his succinctness, it makes his best poems eminently anthologizable. Quite a few lines stay in the memory, as a glance at the Collected Poems' Index of First Lines suggests. He wrote mediocre verse aplenty, but when the eight hundred or more poems are finally reread, certainly some several dozen should survive as an irreducible Selected Poems. Much of the uncollected verse is at Iowa; countless notebooks also exist with Jon Wynne-Tyson, as yet uncataloged.

Iowa has three hundred letters to Gawsworth (hundreds more are at the University of Texas), nearly all from noted writers. This poet who knew everyone is at least memorable as a convivial, literary eccentric. ${ }^{18}$ It is pleasant to recall that in 1970 someone was alive who had known friends of Wilde and Dowson. Gawsworth's sentimental approach to literature certainly had its charm. He had encyclopedic recall of poets' anniversaries over hundreds of years, and he knew their favorite pubs and favorite drinks-and on appropriate occasions put this knowledge to repeated practice. In this age of the committee and the computer, we could use a little more of that. The Gawsworthian anecdotes are endless and are perhaps too easily recalled; from taking home a drunken Dylan Thomas (who stole his shirts), to repeatedly trying to sell his kingdom of Redonda with worldwide news coverage, he delighted the sensational journalists.

Flamboyance aside, his varied published output over 22 years is of astounding bulk: at least 20 verse collections (admittedly overlapping), a couple of dozen poetry broadsides and leaflets, around nine anthologies, 10 or 11 edited collections by other poets, two magazines founded and two others edited, as well as numerous essays and introductions concerning poetry. Add that to more than a dozen books of edited prose and reams of unpublished material, and his achievement by age 41 , though of uneven quality, is phenomenal and, owing to its traditional focus, arguably unique.

18 Special thanks for assisting the research for this article to Mike Ashley, Lucile Coleman, Oliver Cox, S. Edrich, Edward Craig, Betsy Fisher (Nashville Public Library), Stephen W. Foster, Geoffrey Handley-Taylor, John HeathStubbs. Cathy Henderson (University of Texas), R. F. A. Jackson, A. Reynolds Morse, Arthur John Roberts, John D. Squires, and Jon Wynne-Tyson. 
Certainly the image, however tawdry it became, of a poet writing poetry and not settling into stuffy, respectable oblivion is also somewhat compelling in this age of fellowships and "poets in residence."

There are many poems by John Gawsworth which might serve as his own epitaph, crying out as they do at the ravages of Time upon poetry. A happier, less self-pitying example might better serve, however, such as this from the Aylesford Review of summer, 1962:

\section{The Chance}

Love on, nor ever cease to hope;

Love does not exist for some.

It may not come within your scope, It may not ever come.

Yet, if you once but touch its hair Or catch its midnight breathing, You have not failed, although aware Cypress your hands are wreathing. 